\title{
Interview with Filmmaker Pat Murphy
}

\author{
By Desmond Bell
}

Spring 2007 Issue of KINEMA

FILMMAKER Pat Murphy began studying art at the Ulster College of Art and Design and was the first European to spend a scholarship year at the Whitney Museum of American Art. She holds an MA in Film and Television from the Royal College of Arts, London. Pat Murphy was a founder board member of Film Base in 1987, and has taught Film Studies and Film History at a number of institutions. She is currently a lecturer in Film Studies at Queens University Belfast. Her Films include Maeve (1981) Anne Devlin (1984) and Nora (2001) which was selected for the Berlin Film Festival and won the First prize at the Trieste Film Festival for Best Script.

\section{(1) SOURCES}

Desmond Bell: Pat - where did the idea for the film Nora come from?

Pat Murphy: It originally came from Brenda Maddox's book of the same name. ${ }^{(1)}$ I had wanted to do work about Joyce for a long period of time, but actually didn't want to make adaptations from either Ulysses or from Dubliners. A number of films based on these texts already existed even if I wasn't completely happy with some of them, not even with Strick's Ulysses. ${ }^{(2)}$ When I read Brenda Maddox's biography, I was struck by the extent to which I hadn't understood how key Nora Barnacle was to a lot of his work. Other accounts, including the Elman biography ${ }^{(3)}$ place her so much in the background that it's easy to ignore her. Brenda Maddox, however, points out how the all-pervasiveness of Nora's voice in Joyce's writing has paradoxically rendered her invisible to the reader.

In what ways were you able to use the Brenda Maddox biography - obviously you're making a fiction film and clearly it couldn't be an adaptation of the Maddox book. What additional elements had to added to make the script work? Why base your film about Nora Barnacle on her text?

First of all there is the pragmatic issue of securing rights. If you make a film featuring someone as famous as James Joyce you need to buy rights on a biography. Not only because you want to work with the particular insights offered by the biographer, but because you need to define the parameters of your own work. Even with lengthy research one is unlikely to have read everything that has been written about Joyce and you need to protect the film from being sued by people who think you've used their ideas. What Brenda Maddox's book gives is a strong sense of Nora and Joyce's daily life together and I tried to remain faithful to that in the context of a feature film. My earliest draft dealt with Nora's life in Galway, with their lives together in Trieste and culminated with the publication of Ulysses on February 2, 1922 in Paris. It would have played at around four or five hours. There were suggestions that the film should be rewritten as a TV series, but I was firmly committed to making the material work as a feature. So although Brenda's biography covers their entire lives, my final script focused on the period 1904-1912 in the lives of the Joyces. However, I also include scenes that make reference to situations that happened much further on in Nora and Joyce's story.

Biography is a mode of writing in which a factual account of a life is often supplemented with an imaginary reconstruction - how do you think your film deals with the relationship between the factual and the fictive in this exploration of the lives of Nora and Joyce?

Well, the Joyces were real people and whilst certain situations may have to be fictionalised in order to clarify thematic concerns, you are kind of grounded and limited by the established facts about your subjects. Since Joyce drew so much on autobiographical events and on the lives of people around him, making Nora offered a way of approaching Joycean themes and concerns without trying (and failing) to reproduce his work. In a sense you one could argue that there has been a Joycean thread running through my work since my first film Rituals of Memory (1977). Nora was also an opportunity to explore the notion of what a muse represents. How she might ultimately have experienced Joyce's "celebration" of their life together as a distortion and erosion of her self.

The film begins with a condensed account of Nora's early life in Galway and gives some 
privilege to her teenage love affair with Michael Bodkin. Joyce bases his story "The Dead"(4) on this. Later John Huston is to film this. ${ }^{(5)}$ It seems there's a complex level of intertextuality going on here, was this deliberate?

Yes and no. The fact is that one can no longer come to this material with an innocent eye because the references and commentaries are so pervasive and so multi-layered. In approaching Nora film maker - and I think, audiences - bring their knowledge of Joyce's story plus an awareness of how the John Huston film opens up the story to include elements from other parts of Dubliners. Then there is Joyce's inspiration the story. In Rome, Joyce brought Nora to visit Shelley's tomb. Reminded of death, desire and loss Nora confides the story of her first tragic love to Joyce, who then uses it as the basis of "The Dead." So there is a huge level of intertextuality because you can't come to the Michael Bodkin story innocent of the weight of all these other narratives. In fact audiences feel themselves to be so familiar with these narratives, that from my point of view as a film maker, the interest is not in the reveal but in how the story is represented, or rather "performed," since everyone knows what it is. For example, the first part of Nora dealt with her relationship with Michael Bodkin. I wanted to show that there was a whole trajectory to her life before she met James Joyce and that she just didn't exist for him to "discover." However during the editing process, this sequence became telescoped and put together like a memory piece - you see her sitting on the train, and there's a rush of fragmented memories, giving us a sense of what is driving her to run away from Galway. These memories resurface later in the film. I wanted to use the fact that Nora spent many bored and lonely afternoons at the cinema in Trieste and to work with the fiction that an Italian melodrama might trigger sad memories. You get a flash of her at her window with Michael Bodkin waiting below. Then walking in the street she sees Joyce writing in a bar and blurts out this story of a boy who died for love of her. And this is a huge turning point because apart from the real compassion Joyce feels for her pain, he is devastated to realise that he is not her first great love, that all the time she has been haunted by a memory.

Indeed you return to this narrative of remembrance several times in the film. In the bar scene in Trieste the slightly intoxicated Nora joins Joyce in a faltering rendition of The Lass of Aughrim, that's the song that Huston makes central to the performances in The Dead. Later Nora visits the cinema and this triggers memories of Bodkin.

As we discussed earlier, one can't be innocent of the weight of other narratives - yet you have to somehow embrace and reconfigure what went before to express your own perceptions. We know that Nora sang "The Lass of Aughrim" to Joyce when they were in Trieste, that he was thought to be a good singer, interested in how popular music can evoke deep emotion. He uses the song in The Dead to trigger Gretta Conroy's memories and John Huston shows that in his film also. In Nora however, I think the song is used differently. The scene begins with Joyce resenting how ignorant Nora is in front of his friends. Then he joins her in singing "The Lass of Aughrim" a song about a woman abandoned by a fickle lover and the scene becomes about a kind of conflicted tenderness.

There's other structure of intertextuality operating in the film. Joyce and Nora are seen in a loving embrace on top of Howth Head, a scene which again seems to reprise elements of Ulysses. Were you consciously drawing on this source?

Well, Howth Head was a well known courting place for lovers at the time. Probably still is. I mean it's 1904, Nora is working in a hotel and has some afternoons off so what were they to do but walk and talk and find an isolated place to be together. So when he commemorates this in Ulysses, in Molly Bloom's soliloquy, you know it has that reference - that it's a place where courting couples go. I just build on that.

And were there other aspects of Ulysses that you felt it was appropriate to allude to in your own film?

I guess Ulysses inevitably leaves its mark because even though Joyce's male friendships are very well charted in the biographies - you are aware of the beginning of Ulysses as giving the flavour of the dynamic between them. It's not that you're using dialogue or anything, but just getting a sense of Joyce and his friends and the levels of camaraderie and betrayal between them.

I suppose there's also the sense that the whole Molly Bloom character is highly dependant on Joyce's relationship to Nora? And indeed in your film Nora seems to accuse Joyce of virtually stealing her experience and misrepresenting her?

I think it's just in the nature of making work. There are, for example, autobiographical elements in Maeve 
which some members of my family thought were good, but others felt shouldn't have been exposed to the possibility of misrepresentation. I think that you encounter this issue if you are going to make work that has any basis in people's lives.

\section{(2) FEMINIST DISCOURSE}

The film deals with a strong willed young woman Nora Barnacle. Your previous films like Anne Devlin and Maeve also had strong characters making their way within male dominated worlds. Is there a feminist subtext to Nora, a hidden history that's being explored?

There is a certain rescuing, a recuperation taking place in the film. But I really don't think it's a feminist film, in the sense that Anne Devlin or Maeve are.

Maeve sets out in a very conscious way to intervene within filmic discourse. It contends with mainstream narrative structure which is seen as a patriarchal form. The main character Maeve asks questions about the cultural and political narratives she confronts on her return to Northern Ireland at the height of the Troubles. She deconstructs and challenges certain ways of making narratives. The film deals with memory and identity and landscape in a critical way influenced directly by feminist critical thinking. Similarly Anne Devlin is about a woman who literally was written out of history, but unlike in Maeve, here, issues of identity and representation are presented in the context of a chronological and seemingly transparent narrative.

What Nora is doing is something else, I think. Of course it is still dealing with issues of representation because Nora is even now such an unacknowledged influence on Joyce's work. Quite honestly I was interested in Nora because of James Joyce and I feel that the film really is more concerned with charting the course of their relationship than reinstating her place in history.

I think there's more in common between your previous films and Nora than perhaps you want to acknowledge? It seems to me issues around representation and mis-representation become central to this film. Take for instance the key scene where Joyce expresses his disappointment at Nora's apparent lack of interest in his work. She responds very sharply "Why do think I don't read these things, doesn't it occur to you that I couldn't bear to see my life twisted and made strange to me that's living it." There's a real sense here that in addition to the sexual jealously that is the backdrop to this encounter that the issue of representation is central to this dialogue.

Yes, I would accept that. But Nora is not coming from the same ideological trajectory as work like Anne Devlin or Maeve. I wanted to make a love story and was interested in how Irish cinema frequently depicts love and sexuality as dominated by the church, or thwarted and riddled with guilt, despite the fact that Joyce had so radically changed the ways in which men and women can be written about. And it seemed to me, in the Joyce and Nora story, that here were two people who, at an early stage of Irish modernity, 1904, escaped the country and its traditional sexual economy and lived these relatively free lives. Despite some of the more lurid publicity around it, Nora is actually a very restrained film in terms of how the sexuality of the couple is portrayed (think of Winterbottom's Nine Songs or the films of Catherine Breillat). If you look at most mainstream films that deal with sexual transgression initially it's as if the film is proposing a kind of a liberation. Then as the narrative develops the film asserts a traditional morality by punishing the protagonist for their transgressive activity. Like if you think of something like Damage, or Last Tango in Paris the narrative rules that you can show transgressive sex and as sensationally as you want, but someone has to die or at least suffer a lot as a result of their transgression. In Nora my concern was how do make a film that celebrated the sexual liberation of Nora and Joyce but to place this within the context of lives richly lived so that obsessive sexuality is an episode which doesn't dominate the whole piece.

I think Nora is still struggling with these sorts of issues all be it within a different historical and production context. The theme of Joyce's use of Nora as a source is his writing and her profound unease with the appropriation and reworking of her life lead inexorable back to the feminist debate around representation.

Perhaps. In certain ways. But Nora is not a straightforward "feminist film" - I mean I am a feminist, therefore that is going to extend into the films I make. Certainly one of the debates in $70 \mathrm{~s}$ and $80 \mathrm{~s}$ feminism was around the whole issue of representation, and how male directors often ventriloquised female characters. I think it is hugely problematic actually. You have a number of male directors who are seen to be "good 
with women." These are lauded as if recognizing the humanity of women characters is some extraordinary achievement (And yet in a twisted way this adulation is a recognition of how missing, or misrepresented women continue be in contemporary cinema). Whereas when women directors explore the possibility of a uniquely female voice, it's rarely acknowledged or given credit. Also, I think the political and cultural preoccupations were entirely different when Maeve and Anne Devlin were made. In the early 1980s, many Irish film makers were dealing with complex issues around post-colonialism, national identity and the impact of what was happening in the North. Nora was made in 1999 at a particular conjuncture in Irish cinema, when these concerns had dissipated or been reframed in the context of the "Celtic Tiger" and film makers have been forced to consider how best to position themselves in relation to these changes. ${ }^{(6)}$

Nora has sometimes been positioned as a product of the "Celtic Tiger," seen as a lavish costume drama without politics aimed primarily at an international audience. I can't really see it in that context because I'd been trying to make it since 1991 and notwithstanding its financing context, it remains an Irish film.

\section{(3) NEW PRODUCTION FORMATIONS}

\section{This was a difficult film to get off the ground?}

The film received development finance from the Irish Film Board. Tiernan McBride, my partner who was producing the film died suddenly in 1995 there was a question about whether I could go on with the project. I decided that I wanted to complete the film and worked with a number of other producers who were not able to raise the money needed. At that point Ewan McGregor who was on board to play James Joyce, suggested that Nora might be something that could be made through Natural Nylon, the production company which he had set up with actor friends in London. Nora was set up as an Irish-German-Italian co-production with some Eurimages funding as well.

For a while, European cinema was afflicted by so-called "Euro-pudding syndrome" where film narratives were constructed in response to co-production needs. But Nora was a natural European co-production because unlike most Irish people at the time, who headed west to America, the Joyces emigrated east to mainland Europe and became quintessential Europeans. Contrary to popular belief, development and production in the context of European funding actually drives up the budget. Some of our money was coming from Road Movies in Germany so we had to film for a week in Germany.

We constructed most of the Joyce's apartment interiors in the Hamburg Film Studios and filmed most of the love scenes there. That has an impact, I think, on a production, that you go to a place and you film just those kinds of scenes. Also you budget for, say, an eight or nine week shoot which is already extremely tight for a film of this scale and you basically lose a week in travel and setting up in each new place. Basically you go where you have to in order to get the film financed and produced.

Of course the low budget production and distribution world that existed when for example Anne Devlin was made, had completely disappeared by the time Nora came along. Anne Devlin was deliberately cast, crewed and filmed in Ireland and this was a political choice. Up until then Irish cinema and the content of Irish cinema had been determined by forces outside of Ireland, and what we wanted to do was to exercise some measure of control as film makers as to how Ireland was represented.

On one level this low budget strategy is a liberating thing. You are less answerable as an artist to the investors. On another level it's completely problematic - you've a vast amount of work to do and no money to help you do it. On the other hand, when you have co-producers up front, they're already committed, so there's a certain level of distribution that's already set up for the film. With a film like Nora you're conscious that you're entering the world of art house cinema trying to succeed commercially. So if you come from my background as a film maker you can be thrown by that, or you can take it on. It can be an interesting challenge - how do you get your ideas through and make the film you are committed to making while working through those structures.

Indeed. This is a much more sumptuous film than your earlier films, which were very much part of a tradition of a "poor Celtic cinema."(7) W as there a price to be paid with working with a larger budget and within a more commercial context?

Yes. There was also a big advantage to having a larger budget. In a film like Maeve, for example, there was no attention paid to art design. It came from an anti-documentary impulse, yet it was shot like a 
documentary in terms of design. No real attention was paid to costume design, we just bought piles of second hand clothing or the actors used their own. There was little thought to a colour palate or to design as a production element. Although Anne Devlin had a very minimalist aesthetic it drew consciously on old prints and historical narrative painting. I was particularly interested in Vermeer and Georges de la Tour, the ways in which these artists worked with light. With Nora it was different. Whereas Anne Devlin was made in Strokestown House in County Roscommon and in Kilmainham Jail, with Nora we were working in modern cities and in a film studio to reconstruct the look of the past.

It's important, I think, to recognise the importance of costume design in relation to Nora. I was intrigued by the extent to which Joyce and Nora in their real lives focused on clothes, and were endlessly in debt because of their wardrobes. Part of this was living in Trieste at a time when it was the leading resort of the Austro-Hungarian Empire. The notion of promenading - La bella figura - is huge, and the Joyces very much bought into this. So I love the notion that they're being flung out of apartments left, right and centre, but they always try and look extremely elegant. And this is mirrored in my film in the design and the look of their clothes. Its like the clothes are where they live and get their sense of well being not their apartments. It's like that's the architecture within which they live. There's also the extent to which a degree of festishisation occurs on their part with regards their clothing. There's the thing of her underwear...frequently in the letters he writes to her about clothes he wants her to wear, he talks about the quality of velvet, of the things he's going to bring her to wear. I didn't want to have them directly talking about that in the film, but to actually show that emotional investment in fabric and clothes.

The film was funded within a European art house model, rather than Hollywood financing...is this reflected in the aesthetic, do you think?

One of the tasks was to make a film that a general audience could go and see even if they didn't know anything about James Joyce and Nora Barnacle, that they could go and consume that film as if it were a love story. It wasn't possible for me to make a film that would appeal only to Joyceans. ${ }^{\left({ }^{8}\right)}$

You give space in the film Joyce's return to Dublin in 1909 to manage one of Ireland's first cinemas, the Volta. ${ }^{(9)}$ Is this a film makers conceit, or does this section of the film have a structural role.

Yes. Some people say the return was triggered by Nora and her love of films, her suggestion that Joyce should bring cinema to Dublin. He persuaded a number of Triestine businessmen to invest in the scheme of establishing a cinema in Ireland. He went to Dublin to find a venue, and the idea was they would set up the Volta in Dublin and also other cinemas in Cork and Belfast. He seems to have worked very hard as a businessman trying to set up these ventures.

At the same time, there is this encounter with his former friend Cosgrave who tells him that he has slept with Nora. So I'm thinking about what his daily life is like during this period and where I can locate his obsessive feelings of jealousy and loss. And the cinema itself seemed the obvious choice. Strangely, this is a point when they are closest although they are in different countries. The film intercuts between Nora in her bedroom in Trieste and Joyce sitting in the dark, in the Volta cinema. He's in the projection box and you're seeing a fragment of Quo Vadis, being projected, one of the films that was actually shown in the Volta. Then at a later point when Joyce receives a letter from Nora asking him to marry her, we see him sitting with the audience viewing An Easy Way to Pay the Bills. This is one of the Turin films of that period (the Volta programme was dependent on Italian films). It portrays a famous Italian comedian, an insouciant trickster character who evades his debtors by climbing into suitcases and walking through walls. One narrow escape after another. And when I looked at this film, it struck me how weirdly it mirrored Joyce's own life.

You have voiced some unease about the critical response to the film.. What is it that bothers you about how critics write about your work?

Maeve and Anne Devlin were made at a particular conjuncture when there was a great deal of interaction between film makers and the people who were writing critically about cinema. Without being too nostalgic about it-because it was definitely no picnic back then - but was a situation where film culture was engaged in a form of integrated practice. Where the people who were writing critically about film were actually talking to the film makers in a serious and knowledgeable conversation. Conversely the film makers were acutely aware of the critical work that was going and participated in critical discourse. Everything was feeding into 
each other and working off each other. That period had really disappeared by the time Nora was released. Some academics see me as a "former radical film maker" now operating within the art house market, having somehow abandoned my "pure" and "politically aware" past. But this isn't the case. What has happened is there's a whole other set of circumstances governing the production, exhibition and distribution of film. I am inspired by Kaja Silverman's phrase about "being interested in films without a passport" because it's important to challenge boundaries, not to accept the limitations and to somehow create a contested space within the false certainties of all these- issues.

\section{These material forces?}

Yes, exactly. Of course there has been a retrenchment on the part of academics and film critics. There's a sort of divorce between academics and film makers, and I think one of our tasks is to somehow try and recreate conditions for new forms of integrated practice. My experience with Nora was fairly typical - a publicity campaign with its own kind of promotional writing aims to build momentum around the film before it is released. In this, producers are hoping to influence the reviews and indeed some reviewers simply reproduce parts of a film press kit. So there's a huge amount of publicity and promotional work. Its not critical discussion of the film, it's really just about talking the film up - Since a lot of that work focuses on the main actors, this creates a weird conflation between the characters and the actors, and it's a very strange process to witness. Now, when any film comes out of the starting gate it's funnelled through this contemporary distribution machine. Anne Devlin ran for weeks and weeks in various venues, because it built up by word-of-mouth. Now, if you don't get 15,000 people in a day over the first weekend, they take your film off. So that is your primary aim to get past the first weekend. And I think that means there's considerably less space for real critical examination of a film, of how the film works and how it engages with life.

I think you're also implying that film theorists in the academy have their own agendas and there has been a separation between the two spheres.

Yes I think that's true. I think academic film discourse can be quite circumscribed in what it addresses. Academics often write in a manner predominantly shaped by certain fashionable intellectual currents. Certainly from the late sixties from say the socially engaged Film Co-op sort of film, through the Association of Independent film makers and up until say the late eighties there was a sense that film could impact on the world and actually affect it in some way. In discussing film there was something at stake. There was a sense that the criticism and the writing and the film making was part of the same project to do with the renewal of culture and society.

\section{Cinema was an oppositional project?}

Yes, and I think certain spaces and audiences were created from that momentum. I think what's happened since the nineties onwards represents a kind of nihilism on the part of academics where they think the battle is over, like we're never going to have that sort of period of radical work again, so there's a kind of retrenchment. I think it's a loss of belief in...

\section{In the transformative powers of cinema?}

Yes exactly. And I think a lot of film writing that I read these days is really quite cynical and quite narrow intellectually in terms of what its engagement with a broader public might be.

\section{Certainly the fetishization of research in our universities today doesn't help?}

Some academic work I've read is less concerned with the films themselves and how they are produced and more focused on audiences - how for instance women perceive and consume film. In this shift away from the film itself as a cultural practice and intervention it hardly seems to matter which films are chosen on which to exercise these analytical skills. All that can be very interesting but I think it's just a little too dry. The other issue is the rise of "post feminism," which is certainly not a concept that's part of my thinking. Some critical writing has sought to position Nora as a post-feminist text. I would contest that framework of interpretation, although I recognize that there as an attempt to address notions of Female Pleasure-Embodiment-Woman as Spectacle etc. I feel that this approach ignores the very real issues of power and gender that drove my films in the first place, issues which have not yet been satisfactorily resolved. However imperfectly, Nora seeks to keep those issues live. 


\section{Notes}

1. Brenda Maddox, Nora: The Real Life of Molly Bloom (Boston: Houghton Mifflin), 1999.

2. Joseph Strick, Ulysses (1967) UK/ US. 132 min (UK:140 min, USA:123 min).

3. Richard Elman, James Joyce (Oxford: Oxford University Press, revised edition), 1983.

4. James Joyce "The Dead" in his Dubliners (New York: Bantam Publishers), 1990.

5. John Huston, The Dead (1987) UK/ Ireland/ US, 83 min.

6. For a critical account of the Celtic Tiger discourse see Peadar Kirby, The Celtic Tiger in Distress (London: Palgrave), 2002.

7. The term, derived form the Italian art movement Arte Povera was first used by Scottish film writer Colin Mac Arthur, see his "The Cultural Necessity of a Poor Celtic Cinema," in John Hill, Martin McLoone and Paul Hainsworth, Border Crossings: Film in Ireland, Britain and Europe (Belfast: Institute of Irish Studies / BFI), 1994.

8. As Pat Murphy argues elsewhere, "The last ten years has seen endless debate about the way forward for European Cinema. Filmmakers have found themselves following Hollywood models which lay down rigid formulae about how a screenplay can be structured. Time is always tight. Images are climactic and of short duration. There are no gaps for reflection. European cinema is bound up with a sense of place, but now location, which used to be a function of the narrative, is rapidly becoming a function of contemporary funding patterns. Thus a film set in Dublin may end up being filmed in Babelsberg studios, if that's where the finance comes from." From her "Oh! Such Love, Oh Such Suffering," in Michael Tarantino (ed) The Event Horizon (Dublin: Irish Museum of Modern Art), 1996. For a critical discussion of Nora as a costume drama which focuses on the issue of fetish see Geraldine Meaney, Nora (Cork: Cork University Press), 2004.

9. For an account of the film programmes Joyce offered at the Volta in 109 see, Luke McKernan "James Joyce's Cinema," Film \& Film Culture 3, 2004.

\section{Author Information}

Desmond BELL is Head of Film Studies at Queens University Belfast and a documentary film maker. He writes on film and media in Ireland. His film The Last Storyteller? was selected for the New Territories section of the 2002 Venice Film Festival; his Rebel Frontier (2004) is a creative documentary dealing with the Irish and the Finns in the US labour movement. 